\title{
ЕТАПИ ВИХОДЖУВАННЯ НЕДОНОШЕНИХ ДІТЕЙ. РОЛЬ СЕСТРИНСЬКОЇ ДІяльНОСТІ
}

\author{
К. А. Шило, С. О. Никитюк \\ ДВНз «Тернопільський державний медичний університет \\ імені І. Я. Горбачевського МОЗ Украӥни»
}

У статті проаналізовано етапи виходжування недоношених дітей, визначено роль сестринської діяльності.

\section{STAGES OF NURSING CARE OF PREMATURE INFANTS. THE ROLE OF NURSING ACTIVITIES}

\author{
K. A. Shylo, S. O. Nykytyuk \\ I. Horbachevsky Ternopil State Medical University
}

The article analyzes the stages of nursing care of premature infants, defines the role of nursing activities.

Вступ. Недоношеними в загальній популяції, за даними більшості розвинених країн світу, народжуються від 5 до 10 \% дітей. Показник неонатальної захворюваності та смертності недоношених дітей набагато перевищує такий же показник у доношених, причому він значною мірою залежить від ефективності надання медичної допомоги. При правильній організації виходжування, вигодовування та лікування недоношених немовлят, основаних на знанні анатомо-фізіологічних особливостей їх розвитку, принципи гуманістичного неонатального догляду, сучасних підходах до реанімації та інтенсивної терапії ці показники мають чітку тенденцію до зниження.

Правильна організація сестринської допомоги, грамотна тактика медичної сестри, санітарно-гігієнічне виховання та навчання населення чинників здорового способу життя, згідно з сучасними даними науки і практики дозволять поліпшити не тільки прогноз перебігу даного захворювання, а й запобігти розвитку ускладнень на ранніх стадіях.

Основна частина. Виділяють три етапи виходжування недоношених дітей. Перший етап здійснюється в пологовому будинку протягом 5-7 днів для більш зрілих, 8-10 днів для глибоконедоношених. У дітей, народжених із гестаційним віком понад 28 тижнів, також як іу доношених новонароджених, виконується стандартний обсяг заходів із профілактики: осушуються

(c) К. А. Шило, С. О. Никитюк, 2018 шкірні покриви, дитину обгортають в теплі стерильні пелюшки, але оскільки у них значно вищий ризик розвитку гіпотермічних станів стандартні заходи повинні виконуватися з особливою ретельністю [4].

В обов'язки медичної сестри на цьому етапі входить підтримка:

1) теплового та бактеріологічного режимів;

2) сенсорна стимуляція у вигляді дотику, погладжування і бесіди з ним;

3) терапія сурфактантом;

4) охоронного режиму (обмеження світлових, звукових, больових подразників);

5) зважування щодня, попереджаючи переохолодження дитини та забезпечуючи зміну інкубатора;

6) надання комфортного фізіологічного положення.

Дитина, яка народилася з масою тіла менше 1500 г, може бути виписана додому під нагляд дільничного лікаря-педіатра за таких умов: маса тіла 2000 г і більше; загальний стан дитини задовільний і відповідає наступним ознакам: а) самостійне дихання адекватне $з$ частотою 30-60 за хв; б) відсутність втягання податливих ділянок грудної клітки; в) відсутність апное щонайменше протягом 7 діб до дня виписування; г) відсутній ціаноз шкіри і слизових оболонок; дитина може підтримувати стабільну нормальну температуру тіла щонайменше 3 доби поспіль до дня виписування; дитина засвоює належний добовий обсяг харчування і стабільно збільшує масу тіла (щонайменше 20 г на добу про- 
тягом 3 діб поспіль до дня виписування); зроблені всі профілактичні щеплення та скринінгові дослідження; пуповинний залишок або ранка сухі та чисті, без ознак запалення; мати або члени сім'ї проінформовані та навчені догляду за дитиною: а) спостерігати за загальним станом і розвитком дитини; б) годувати дитину грудьми за вимогою і догодовувати, у разі необхідності, зцідженим грудним молоком; в) контролювати температуру тіла дитини та підтримувати їі в межах 36,8-37,2 ${ }^{\circ} \mathrm{C}$; мати або члени сім'і проінформовані про загрозливі стани дитини, при яких негайно потрібно звертатися за медичною допомогою: а) дитина погано смокче груди; б) дитина млява або збудлива; в) у дитини виникли судоми; г) у дитини порушення дихання: часте (більше 60 дихань за хв або утруднене); д) у дитини гіпотермія (температура тіла дитини менше $36,5^{\circ} \mathrm{C}$ ) або гіпертермія (температура тіла дитини більше $\left.37,5^{\circ} \mathrm{C}\right)$; е) визначається набряк, гіперемія або нагноювання пупкової ранки; є) у дитини блювота або діарея; мати також попереджена про заходи профілактики синдрому раптової смерті (рекомендовано сон на спині; не курити в приміщенні, де перебуває дитина; не накривати обличчя дитини під час сну).

Другий етап виходжування. На цьому етапі створення та підтримки оптимальнихумов для виходжування дитини їі поміщають в кувез. І, як раніше було сказано, в обов'язки медичних сестер входить:

1) спостереження за положенням тіла, щоб уникнути застійних явищ і деформацій;

2) підтримання теплового режиму;

3) охоронний режим (обмеження світлових, звукових, больових подразників);

4) сенсорна стимуляція у вигляді дотику, погладжування і бесіди з ним;

5) регулярне проведення дезінфекції кувеза;

6) створення спеціальних - гніздечок;

7) контроль дихання;

8) моніторинг маси тіла;

9) контакт і участь батьків у виходжуванні;

10) ентеральне і парентеральне харчування дітей з ЕНМТ і ДНМТ;

11) підтримання балансу рідини та електролітів.

Критерієм виписки дитини на поліклінічну дільницю з 2-го етапу: дитина може утримувати температуру тіла у відкритому ліжку не менше 1-2 доби (24-48 год); харчується з пляшечки або грудей матері, позитивна динаміка маси тіла (2000 г і більше) [5].

Третій етап виходжування. Головна роль медичної сестри - здійснення роботи із профілактики інвалідності, формування здорової дитини та надання ме- дичної допомоги дітям із різною патологією вдома 3 метою виконання рекомендацій лікаря.

Для вирішення ряду завдань медична сестра виконує великий комплекс заходів:

- спільно з дільничним лікарем-педіатром приймає недоношених дітей з моменту виписування зі стаціонару до трьох років;

- забезпечує систематичність спостереження педіатром, окулістом, неврологом, сурдологом, ортопедом;

- контролює, наскільки правильно батьки виконують лікарські призначення;

- здійснює планування проведення вакцинації недоношеним дітям;

- своєчасно організовує планові медичні огляди дітей, які перебувають на диспансерному обліку;

- контролює виконання лікувальних процедур вдома за призначенням лікаря;

- допомагає лікарю при проведенні медичних оглядів дітей (здійснює антропометрію, оформляє необхідні довідки, рецепти, направлення на дослідження і т. д.);

- консультує батьків із вибору лікувального харчування, медикаментозної терапії та профілактики захворювань (ЛФК, масаж, Війта-терапія, фізіотерапія, тонкий пальцевий тренінг);

- розрахунок добового, разового обсягу їжі, складання меню при грудному вигодовуванні. Складання меню дитині на змішаному і штучному вигодовуванні [8].

Висновки. Для повного задоволення в догляді за недоношеною дитиною велика роль «лягає на плечі» медичних сестер. Вони ведуть всю документацію, просвітницькі роботи, бесіди. Маючи вищу категорію та великий стаж, не завжди вдається під час прийому поговорити з батьками, дати рекомендації. Для полегшення роботи медичних сестер необхідно організувати сайт відділення, де в електронній версії будуть викладені:

1) відповіді на часті запитання;

2) відео-уроки з правильного прикладання до грудей, підгодовування і т. д.;

3) відео-уроки масажу і ЛФК.

Створення пам'яток, брошур про режим дня, харчування, які могли 6 видаватися на руки батькам при кожному відвідуванні у відділення. Проведення майстер-класів із масажу та ЛФК під керівництвом досвідчених фахівців. Лікування недоношених дітей - це насамперед догляд, який включає заходи, що сприяють стабілізації стану дитини і забезпечують успіх усього лікування, в якому провідна роль належить медичним сестрам. 


\section{СПИСОК ЛІТЕРАТУРИ}

1. Про затвердження Протоколу медичного догляду за новонародженою дитиною з малою масою тіла при народженні : наказ від 29.08.2006 р. № 584.

2. Неонатологія : навч. посіб. / Ю. К. Больбот, Р. В. Ковтуненко, М. В. Калічевська, Т. А. Бордій. - Дніпропетровськ : АРТ-ПРЕС, 2013. - С. 38-45.

3. Добрянський Д. О. Початкова допомога глибоконедоношеним дітям після народження - сучасні пріоритети / Д. О. Добрянський // Неонатологія, хірургія та перинатальна медицина. - 2011. - Т. 1, № 1. - С. 108-112.

4. Моісеєнко Р. О. Аналіз захворюваності дітей першого року життя в Україні / Р. О. Моісеєнко // Перинатологія і педіатрія. - 2010. - № 1 (41). - С. 6-9.

5. Неонатологія : навч. посіб. / за ред. П. С. Мощича, О. Г. Суліми. - К. : Вища школа, 2014. - С. 17-42.

6. Педіатрія : підручник для студентів вищих медичних закладів IV рівня акредитації / за ред. О. В. Тяжкої. Вінниця : Нова Книга, 2008. - С.178-193.

7. Підручник з реанімації новонароджених / [Американська Кардіологічна Асоціація, Американська Академія Педіатрії ; за ред. Дж. Катвінкела]. - Львів : Галицька видавнича спілка, 2007. - 264 с.

8. Посібник з неонатології / Джон П. Клоерті, Ерік К. Ейхенвальд, Енн Р. Старк; пер. з англ. - [Шосте видання]. К. : Фонд допомоги і розвитку дітям Чорнобиля; Вид-во «Фенікс», 2010. - 856 с.

9. Реальность, проблемы и возможности выхаживания недоношенныхдетей смассойтелапри рождении<1500г/
Н. М. Пясецкая, О. Т. Лакша, Т. А. Орлова [и др.] // Современная педиатрия. - 2014. - № 4 (5). - С. 136-138.

10. Сахарова Е. С. Современные принципы патогенетического лечения анемий недоношенных детей / Е. С. Сахарова, Е. С. Кешишян // Российский вестник перинатологии и педиатрии. - 2014. - № 1. - С.16-20.

11. Современные тенденции проблем вскармливания недоношенных детей / В. А. Скворцова, Т. Э. Горовик, О. Л. Лукоянова [и др.] // Вопросы современной педиатрии. - 2015. - № 2. - С. 80-87.

12. Шабалов Н. П. Неонатология : учебник : в 2 т. / Н. П. Шабалов. - 5-е изд., Т. 2. - СПб. : Питер, 2011. С. 357-384.

13. Шегедин М. Б. Медсестринство в терапії / М. Б. Шегедин, І. А. Шуляр. - Дрогобич: Відродження, 2006. - 225 с.

14. Шунько $€$. $Є$. Впровадження концепції подальшого розвитку перинатальної допомоги в Україні / Є. Є. Шунько // Неонатологія, хірургія та перинатальна медицина. 2011. - T. 1, № 1. - C. 10-16.

15. Berger R. Perinatal brain injury / R. Berger, Y. Garnier // J. Perinatal. Med. - 2000. - Vol. 28, No. 4. - P. 261-285.

16. Ichani R. Respiratory distress in the newborn / R. Ichani // Child. Health. - 2004. - Vol. 33, No. 2. - P. 82-84.

17. Interfacial properties of pulmonary surfactant layers / R. Wustneck, J. Perez-Gil, N. Wustneck [et al.] // Adv. Colloid Interface Sci. - 2005. - Vol. 117, No. 1. - P. 33-58. 